\title{
Sentença judicial proferida por força de prevaricação, concussão e corrupção do juiz: nulidade ou inexistência do ato jurídico?
}

\author{
Judicial sentence given for prevarication, concussion and corruption of judge: null or non-existence
}

of the legal act?

Sentencia judicial dada por prevaricación, concusión y corrupción del juez: ¿nula o no existencia

del acto legal?

Recebido: 08/02/2021 | Revisado: 14/02/2021 | Aceito: 18/02/2021 | Publicado: 27/02/2021

\author{
José Miguel Garcia Medina \\ ORCID: https://orcid.org/0000-0002-3669-5145 \\ Universidade Paranaense, Brasil \\ E-mail: josemedina@prof.unipar.br \\ Mariana Sartori Novak \\ ORCID: https://orcid.org/0000-0002-4904-152X \\ Universidade Paranaense, Brasil \\ E-mail: mariana-novak@ hotmail.com \\ Diogo de Araujo Lima \\ ORCID: https://orcid.org/0000-0001-8416-1327 \\ Universidade Paranaense, Brasil \\ E-mail: diogo_araujo_lima@hotmail.com
}

\begin{abstract}
Resumo
O presente estudo visa analisar a hipótese de cabimento do meio autônomo de impugnação conhecido como ação rescisória, quando configurada a hipótese do art. 966, I, do Código de Processo Civil, que trata da decisão proferida por força de prevaricação, concussão ou corrupção do juiz. O objetivo é investigar, sob uma ótica da escada ponteana dos planos do ato jurídico, se o defeito da decisão prolatada nessas circunstâncias fulmina a validade ou a própria existência do ato jurídico, alcançando-se, em desfecho, o entendimento pela segunda hipótese. Analisam-se os efeitos processuais decorrentes da referida constatação, mormente quanto ao instrumento cabível para impugnação. Utilizase, para tanto, o método dedutivo, onde se parte da possibilidade geral, contemplada no retromencionado dispositivo, para análise específica sob o prisma dos planos do ato jurídico. Tem objetivo metodológico em seu viés propositivo. O trabalho pautar-se-á em pesquisa bibliográfica e análise do texto legal, de jurisprudência e de artigos acadêmicos.

Palavras-chave: Inexistência jurídica; Nulidades; Sentença; Concussão; Corrupção; Prevaricação.
\end{abstract}

\begin{abstract}
The present study aims to analyze the hypothesis of fit of the autonomous means of challenge known as rescission action, when configured the hypothesis of art. 966, I, of the Civil Procedure Code, which deals with the decision rendered by virtue of the judge's malfeasance, concussion or corruption. The objective is to investigate, from the point of view of the Pontian ladder of the plans of the legal act, if the defect of the decision made in these circumstances fulminates the validity or the very existence of the legal act, reaching, in the end, understanding by the second hypothesis. The procedural effects arising from the said finding are analyzed, especially as regards the appropriate instrument for challenge. For this purpose, the deductive method is used, based on the general possibility, contemplated in the above mentioned device, for specific analysis under the prism of the plans of the legal act. It has a methodological objective in its propositional bias. The work will be based on bibliographic research and analysis of the legal text, jurisprudence and academic articles.
\end{abstract}

Keywords: Legal inexistence; Nullities; Verdict; Concussion; Corruption; Prevarication.

\section{Resumen}

El presente estudio tiene como objetivo analizar la hipótesis de adecuación de los medios autónomos de impugnación conocidos como acción de rescisión, cuando se configura la hipótesis del arte. 966, I, del Código de Procedimiento Civil, que se ocupa de la decisión dictada en virtud de la mala conducta, conmoción cerebral o corrupción del juez. El objetivo es investigar, desde el punto de vista de la escalera pontiana de los planes del acto jurídico, si el defecto de la decisión tomada en estas circunstancias fulmina la vigencia o la existencia misma del acto jurídico, llegando, en definitiva, la comprensión por la segunda hipótesis. Se analizan los efectos procesales derivados de dicha constatación, especialmente en lo que respecta al instrumento de impugnación adecuado. Para ello, se utiliza el método deductivo, basado en la posibilidad general, contemplada en el dispositivo antes mencionado, de un análisis 
específico bajo el prisma de los planes del acto jurídico. Tiene un objetivo metodológico en su sesgo proposicional. El trabajo se basará en la investigación bibliográfica y el análisis del texto jurídico, jurisprudencia y artículos académicos.

Palabras clave: Ausencia legal; Nulidades; Veredicto; Concusión; Corrupción; Prevaricación.

\section{Introdução}

A necessidade de uma resposta definitiva aos conflitos levados ao Poder Judiciário encontra sua matriz na ideia de segurança jurídica. Todavia, mesmo elevada à categoria de garantia fundamental (art. $5^{\circ}, \mathrm{XXVI}, \mathrm{CF}$ ), a coisa julgada pode vir a ser mitigada e dar lugar à possibilidade de um julgamento mais próximo dos ideais de justiça, sendo que tal se dará apenas em situações consideradas graves e dentro de determinado prazo legal. Assim, o tema está intimamente ligado ao da ação rescisória, pois é por intermédio dela que o ordenamento busca contemporizar o binômio justiça versus segurança jurídica. A particularidade é que, transcorrido o prazo para ajuizamento da ação rescisória, a coisa se torna "soberanamente julgada", não podendo mais, em tese, ser revista.

A limitação atinge decisões maculadas de algum tipo de nulidade, ou seja, aquelas que, apesar de viciadas, produzem efeitos e formam a coisa julgada. Não alcança, porém, decisões consideradas juridicamente inexistentes, pois, justamente por se tratarem de um não ato, são incapazes de formar coisa julgada, não se submetendo a prazo previamente definido para impugnação.

Uma das hipóteses de rescindibilidade previstas no atual Código de Processo Civil é a da decisão proferida por força de prevaricação, concussão ou corrupção do juiz (art. 966, I). Ao considerar causa de rescisão do julgado, o legislador partiu da premissa de que a decisão existe no plano jurídico e, como tal, encerra aptidão para produzir coisa julgada. A questão é que, se confrontada com a Teoria Geral do Processo, a premissa pode não se mostrar a mais adequada, na medida em que a jurisdição, que constitui um dos pressupostos de existência da relação jurídico-processual, tem como uma de suas principais características a imparcialidade.

Assim, é preciso analisar se a hipótese tratada pelo legislador como caso de invalidade efetivamente se adéqua à Teoria Geral do Processo e se realmente não está diante de uma causa de inexistência da relação jurídico-processual.

Para enfrentar o tema, a primeira parte do trabalho será dedicada a explanar os planos da existência e da validade do ato jurídico, bem como a via processual para alegação e possível solução dos vícios que podem acometê-los. Na segunda, tratar-se-á, brevemente, do conceito de jurisdição e de suas elementares características. Na terceira, aborda-se a hipótese ventilada no art. 966, I, do CPC/2015, correlacionando-a com os pressupostos de existência da relação processual, mais especificamente com a jurisdição.

\section{Metodologia}

A pesquisa será desenvolvida por meio do método dedutivo, no qual, conforme aduzem Eva Maria Lakatos e Marina de Andrade Marconi (2003, p. 92), sendo verdadeiras as premissas, a conclusão também o será e a totalidade da informação que corresponde à conclusão já estava, mesmo que de forma implícita, inserida nas premissas.

Na presente análise, verifica-se a hipótese contida no art. 966, I, do Código de Processo Civil, concernente à possibilidade de impugnação da decisão de mérito proferida por força de prevaricação, concussão ou corrupção do juiz, em cotejo com estudo, ainda que breve, dos planos do ato jurídico, com o objetivo de investigar o vício, ou inexistência, da decisão proferida nessas circunstâncias.

A pesquisa pode ser classificada como qualitativa, em cujo âmbito pode ser considerada como meio de análise de um fenômeno dentro do contexto em que é inserido, ou seja, de modo integrado (Godoy 1995, p. 21). Investigou-se, sob tal perspectiva, a prolação da decisão nas hipóteses mencionadas e as consequências processuais do respectivo enquadramento nos 
planos do ato jurídico, elaborando-se conceitos e hipóteses, considerando a impossibilidade de quantifícação de dados em casos tais como o enfrentado (Pereira, 2018).

Utilizar-se-á o método bibliográfico para a investigação, pautado em pesquisa de doutrina, jurisprudência e legislação vinculada ao objeto de estudo.

\section{Resultados e Discussão}

\subsection{Nulidades e inexistência jurídica}

Adotamos, no presente estudo, a teoria que reconhece haver três planos que envolvem os atos jurídicos, dentre os quais os atos processuais. São eles: existência, validade e eficácia. A escada ponteana, em alusão ao idealizador da teoria (Miranda, 1974, p. 15), indica os três patamares que o ato jurídico precisa preencher para ser considerado perfeito. Embora tais patamares sejam estanques entre si, é possível falar que o preenchimento de um pressupõe o de outro. ${ }^{1}$

A existência do ato jurídico-processual passa pelo ser ato, que se aperfeiçoa quando do preenchimento, pelo arcabouço fático, de pressupostos que redundam na incidência da norma. Calmon de Passos (1988) esclarece que não há como negar a existência material dos fatos, porém, é certo que tais hipóteses não são aptas a corresponder ao tipo normativo. Os vícios identificados no plano da existência são suscetíveis de impugnação por meio de pretensão declaratória. A partir do momento em que se detecta a inexistência, não mais se fala em ato viciado. A razão é simples: defeito pressupõe existência (Araujo, 2016, p. 427).

Já a validade do ato "[...] diz respeito à eficiência com que o seu suporte fático foi preenchido. Se houver o preenchimento da hipótese de incidência [...] de maneira deficiente, surgirá defeito que pode autorizar a nulificação do ato". (Didier Jr., 2017, p. 451) Nesse plano, encontra-se o que se conhece como nulidades propriamente ditas.

Avançando para o plano da eficácia, fala-se em efetiva produção de efeitos típicos (Alvim, 2019, p. 111) ou na possibilidade de produção desses efeitos. Na grande maioria das vezes, se um ato é válido, é sucessivamente apto a produzir efeitos (Tesheiner, 2001, p.18). O estudo dos planos da existência, da validade e da eficácia é fundamental para delimitar o vício que acomete o ato jurídico e a forma de saná-lo.

Dentro das diversas classificações, parte da doutrina distingue as nulidades em relativas e absolutas. ${ }^{2}$ Aquelas, se não alegadas pela parte no primeiro momento em que lhe couber falar nos autos, serão sanadas pelo mero decurso do tempo (preclusão temporal). Essas, por sua vez, e para essa parcela da doutrina, suplantam a própria coisa julgada e, em determinadas hipóteses, ${ }^{3}$ podem ser objeto de ação rescisória, ${ }^{4}$ no prazo de dois anos (art. 975, CPC), findo o qual tornam-se insuscetíveis de impugnação.

Os casos de inexistência, por sua vez, não encontram semelhante limitação temporal, na medida em que poderão ser questionados, a qualquer tempo, por meio do meio autônomo de impugnação conhecido como "querela nullitatis".5

\footnotetext{
1 Teresa Arruda Alvim entende que atos inexistentes ou inválidos são aptos, sim, a produzir efeitos, desde que tal seja possível fática, material e concretamente, ao passo que Cândido Rangel Dinamarco não compartilha de tal opinião, por exemplo. DINAMARCO, Candido Rangel (2009). Litisconsórcio. (8a. ed.) São Paulo: Malheiros como citado por Alvim, T. A. (2019). Nulidades do Processo e da Sentença. (10a. ed). São Paulo: Thomson Reuters Brasil.p. 409.

${ }^{2}$ Há quem discorde dessas classificações, como, por exemplo, Luiz Guilherme Marinoni e Sergio Cruz Arenhart. Para os autores, não há que se falar em classificações de nulidades em cominadas ou não cominadas, ou absolutas e relativas. Segundo eles, é adequado trabalhar nos domínios do direito processual civil simplesmente com o termo invalidade ou nulidade. "O ato processual será nulo sempre que a infração à forma comprometer os fins de justiça do processo, frustrando o alcance de sua finalidade, ou causando prejuízo”. (Marinoni, L. G \& Mitidiero, D. (2017). Novo Código de Processo Civil Comentado. São Paulo: Revista dos Tribunais. p. 372)

${ }^{3}$ Teresa Arruda Alvim leciona, contudo, que "Não há nulidade de pleno direito [absoluta] que não se encarte nas previsões legais para o cabimento da ação rescisória”. Alvim, T. A. (2019). Nulidades do Processo e da Sentença. (10a. ed). São Paulo: Thomson Reuters Brasil., p. 428.

${ }^{4}$ Com exceção do inc. VII, do art. 966, CPC, que dispõe acerca de prova nova.

${ }^{5}$ José Miguel Garcia Medina prefere a utilização do termo “ação declaratória de inexistência” cf. p. 1451 do Código de Processo Civil comentado, 2020.
} 
Apesar da denominação legal, por meio da "querela nullitatis" almeja-se uma declaração de inexistência do ato jurídico. A medida visa extirpar do ordenamento uma incerteza jurídica. Do caráter predominantemente declaratório advém a nota de imprescritibilidade. Ao tratar do tema, Enrico Tullio Liebman (1947, p. 183, como citado por Theodoro, 1980, p. 23) esclarece:

há vícios maiores, vícios essenciais, vícios radicais, que sobrevivem à coisa julgada e afetam a sua própria existência. Neste caso a sentença embora se tenha tornado formalmente definitiva, é coisa vã, mera aparência, [assim], em todo tempo se pode opor contra ela, que é nenhuma.

A partir de uma abordagem taxativa e inflexível das categorias jurídicas até aqui mencionadas, não se cogita da utilização da ação rescisória para hipóteses de inexistência de sentença, afinal esse instrumento processual possui prazo decadencial para sua propositura e, caso se assumisse a possibilidade, após escoado o lapso temporal sem sua propositura, poderia se suscitar a ideia da existência de sentenças juridicamente inexistentes. E o que não existe, não passa, com o tempo, a existir. ${ }^{6}$ Ademais, o trânsito em jugado da decisão rescindenda constitui uma das exigências previstas no art. 966, "caput", do CPC/2015. Se a sentença não existe, não transita em julgado.

Apesar disso, parte da doutrina admite a fungibilidade entre os meios autônomos de impugnação ou mediante a declaração de inexistência consagrada em outros instrumentos processuais 7 . Invocam-se, em abono a essa orientação, os princípios da celeridade e da instrumentalidade das formas que informam o atual Código de Processo Civil (Medina, 2017, p. 1002, \& Alvim, 2019, p. 440).

Não é comum o texto legal enunciar as hipóteses de atos processuais inexistentes. Nem precisaria. Isso porque, "se se pratica um ato tão disforme do modelo legal, que em si mesmo não seja ato a atingir o resultado desejado, não precisaria a lei negar-lhe eficácia" (Grinover, Dinamarco \& Cintra, 2015, p. 423) O Código de Processo Civil de 2015 não utiliza em momento algum essa expressão, ao passo que o CPC/1973 o mencionou timidamente quando tratou da inexistência dos atos praticados pelo advogado sem mandato (art. 37).

Teresa Arruda Alvim explicita que a sentença juridicamente inexistente não é apta nem mesmo a ostentar o "nomen iuris", uma vez que detentora de defeito tão grave que a desqualifica como sentença. Segundo a autora, o defeito pode advir tanto de situação extrínseca, proveniente do curso do processo (ex.: sentenças de mérito de processo carente de pressuposto processual de existência), como intrínseca, originada da própria decisão (ex.: sentença sem capítulo decisório ou não assinada pelo juiz).

Incontroverso que não há como determinar todas as hipóteses de inexistência da sentença (Alvim, 2019, p. 416-418), pois, "o grau de afastamento do modelo legal é algo que não pode ser minudentemente descrito pelo legislador: há infinitos graus, inúmeras possibilidades.”(Alvim, 2019, p. 412).

Fernando da Fonseca Gajardoni (2000, p. 19) compartilha do mesmo entendimento, ao realçar que os pressupostos de existência do processo como "requisitos mínimos para a própria constituição da relação jurídica processual”, se ausentes, configuram inexistência, também, da própria prestação jurisdicional veiculada na sentença. Segundo o autor, dentre os pressupostos processuais de existência, encontram-se a citação, o procedimento, a jurisdição e a capacidade postulatória (2000, p. 19). A título exemplificativo, Teresa Arruda Alvim (2019, p. 416) elenca a citação, a petição inicial e a jurisdição como pressupostos de existência da relação jurídico-processual, os quais estão ligados "fundamentalmente à ideia de relação processual trilateral."

\footnotetext{
${ }^{6}$ Acórdão reformado no EDcl no RE 62.128/SP, Pleno, j. 14.03.1973, rel. Min. Aliomar Baleeiro, DJ 13.04.1973).

${ }^{7}$ José Miguel Garcia Medina exemplifica, lastreado em vasta jurisprudência, acerca da possibilidade de se veicular o conteúdo da ação rescisória, mais especificamente acerca da ausência de citação do réu, por Mandado de Segurança, impugnação à execução de sentença e Ação Civil Pública (Medina, J. M. G. (2020). Código de Processo Civil comentado. (6a. ed.) São Paulo: Revista dos Tribunais., p. 1452).
} 
O raciocínio nada mais é que a pura sistematização da relação jurídica-processual idealizada por Oskar Von Bülow, em sua obra "Teoria dos Pressupostos Processuais e das Exceções Dilatórias" (como citado por Grinover, Cintra \& Dinamarco, 2015, p. 320), na qual enunciava a imprescindibilidade da presença dos três sujeitos processuais (autor - pela petição inicial; réu - pela citação; Estado-juiz - pela jurisdição) para existência e possível desenvolvimento válido do processo.

\subsection{Noções acerca da jurisdição}

\subsubsection{Breve introito}

$\mathrm{Na}$ acepção originária do termo, derivada do latim "juris dictio", jurisdição significaria "dizer o direito", não no sentido de apenas declará-lo, mas de fazer com que o ordenamento jurídico seja respeitado em cada decisão. Trata-se do "poder-dever de realização do Direito, específico dos órgãos do Poder Judiciário" (Tucci, 2011, p. 1), que ocorre por meio de uma atividade substitutiva dos membros da comunidade. Para Chiovenda, a substituição da atividade dos particulares pelo agir de órgãos públicos constitui uma forma de se afirmar a existência da vontade da lei, a fim de que seja possível colocá-la em prática, ao passo que Carnelutti a enxerga como meio de se alcançar a justa composição da lide (1989, p. 369 como citado por Carneiro, 2012, p. 27).

A jurisdição consiste na função estatal, por meio da qual o Estado substitui os titulares dos interesses em conflito para que, de modo imparcial, resolva o caso concreto pela atuação do direito (Grinover, Cintra \& Dinamarco, 2015, p. 165). Gian António Michelli discorre que a jurisdição é função que se diferencia da administração não apenas pelo conceito simplista de substituição, mas também pelo caráter de imparcialidade que deve orientar as decisões do Poder Judiciário (1947, como citado por Tucci, 1988, p. 7). A jurisdição, de acordo com Frederico Marques (1971), é a única via capaz de atender os imperativos da vida jurídica que o Estado impõe, daí porque a tutela jurisdicional é inafastável de qualquer lesão ou ameaça de lesão a direito (art. $\left.5^{\circ}, \mathrm{XXXV}, \mathrm{CF}\right)$.

Enrico Tullio Liebman (1985, p. 3) leciona que

há um ramo do direito destinado precisamente à tarefa de garantir a eficácia prática e efetiva do ordenamento jurídico, instituindo órgãos públicos com a incumbência de atuar essa garantia e disciplinando as modalidades e formas da sua atividade. Esses são os órgãos judiciários e a sua atividade chama-se, desde tempos imemoriais, jurisdição (iurisdictio).

Ada Pellegrini e outros (2015, p. 166) explanam o caráter multifacetário da jurisdição, que, a um só tempo, é poder, função e atividade: poder, por corresponder ao poder estatal adjetivado pelo caráter imperativo das decisões; função, por contemplar o dever dos órgãos jurisdicionais de promover, por meio da aplicação do direito justo e de regras processuais previamente definidas, a pacificação social; e atividade, concebida como o plexo de atos do juiz dentro do processo, exercendo o poder e cumprindo a função que lhe é atribuída por lei. Essas características somente aparecem por meio de um processo adequadamente estruturado, ou seja, que observe o devido processo legal.

A pacificação de conflitos só pode ser realizada, ou por quem não é parte do processo, ou por quem não tem interesse algum sobre ele. Se o Estado se arvorou dessa função/atividade/poder, não pode estar no mesmo nível que as partes, mas acima delas, para que, por meio do processo, consiga aplicar a essência do ordenamento jurídico, que foi violado naquele momento por algum conflito. O que se persegue imediatamente é a implementação "[...] do direito objetivo e de modo mediato a tutela do direito subjetivo, a solução da lide. Satisfaz-se, em primeiro plano, o interesse da sociedade e, por via de consequência, o interesse das partes." (Watanabe, 1980, p. 14-22). 
Não há dúvidas de que a parte, ao ingressar em juízo, não pretende alcançar a paz social ou o restabelecimento do ordenamento jurídico, mas que seu interesse seja atendido em determinado conflito. Por isso, o conceito de jurisdição deve ser analisado tanto sob a forma extrínseca como intrínseca ao conflito levado ao Judiciário.

\subsubsection{Características essenciais}

Uma das principais notas da jurisdição remete à unidade. Como manifestação da soberania estatal, a jurisdição é una e indivisível, independentemente da coexistência, para fins de distribuição e efetividade da atividade jurisdicional, de diversos órgãos que a exercem, por meio das respectivas competências. Decorre daí, também, o princípio da aderência ao território, pois a jurisdição, ainda que segmentada, só pode ser exercida dentro do território nacional, em decorrência da unidade da soberania.

A inafastabilidade do Poder Judiciário, ou, como prefere Ada Pellegrini e outros (2015, p. 173), princípio do controle jurisdicional, descrito no art. $5^{\circ}, \mathrm{XXXV}$ da $\mathrm{CF}$, constitui outra característica da jurisdição. Em resumo, compreende-se que não pode a lei excluir da apreciação do Poder Judiciário lesão ou ameaça a direito. Trata-se de garantia de que todos tenham acesso ao Judiciário, que não poderá deixar de atender quem a ele recorre com pretensão amparada no ordenamento jurídico.

$\mathrm{O}$ direito de ação, que difere do chamado direito de petição, ${ }^{8}$ pode ser considerado como um direito subjetivo à sentença, seja de acolhimento, quer de rejeição da pretensão (Nery Jr., 2017, p. 217). A questão relaciona-se intimamente com a disposição legal que determina a atuação do juiz, no sentido que ele "não se exime de decidir sob a alegação de lacuna ou obscuridade do ordenamento jurídico" (art. 140 do CPC/2015). Se ao indivíduo é garantido o acesso ao Poder Judiciário, não é lógico que a respectiva pretensão não possa ser analisada ao pretexto de ausência de amparo legal. A própria a norma do art. $4^{\circ}$ da Lei de Introdução às normas do Direito Brasileiro (Decreto-Lei n. ${ }^{\circ}$ 4.657/1942) estatui que "Quando a lei for omissa, o juiz decidirá o caso de acordo com a analogia, os costumes e os princípios gerais de direito" ${ }^{9}$ e desse modo, é possível asseverar que, via de regra, o princípio da inafastabilidade não admite exceções.

Outra característica salutar e inerente à jurisdição é a sua inércia. Ela só atua quando devidamente provocada. Descrito no art. $2^{\circ}$ do CPC, o princípio da inércia da jurisdição é princípio democrático fundamental, uma vez que, nas democracias, prima-se pela liberdade dos indivíduos, salvo o que é proibido ou imposto por lei. Ao indivíduo é que pertence a decisão de se valer, ou não, do Poder Judiciário para solução de seus conflitos (Passos, 2008, p. 220). Há, aqui, nítida manifestação do status libertatis (ou negativo), uma das formas de manifestação de status do cidadão frente ao Estado (Medina, 2020, p. 131).

Pela ideia de indelegabilidade, igualmente peculiar ao instituto processual em estudo, compreende-se a impossibilidade de se alterar o órgão que a Constituição Federal estabeleceu como sendo competente, seja por lei, quer por deliberação dos membros de qualquer dos poderes. Sob o viés interno do Judiciário, não se admite a um membro delegar função a outro membro e/ou órgão, pois quando um magistrado atua o faz em nome do Estado que o investiu (Grinover, Cintra \& Dinamarco, 2015, p. 173). Lembre-se que uma das características da investidura é a de que só pode exercer a jurisdição aquele devidamente investido na função de juiz.

Já a inevitabilidade corresponde ao fato que as partes não necessitam aceitar a jurisdição ou o resultado do julgamento, cuja implementação independe da vontade dos litigantes, fruto do poder de coerção derivado da soberania estatal (Cunha \& Freire, 2017, p. 73-75).

Costuma-se afirmar que outra característica indissociável da ideia de jurisdição é a produção da coisa julgada. A partir do momento que a sentença passa a ser insuscetível de recursos, torna-se imodificável, seja dentro do processo (coisa julgada

\footnotetext{
${ }^{8}$ Conforme elencado no art. $5^{\circ}$, XXXIV, "a”, da Constituição Federal.

${ }^{9}$ Art. $4^{\circ}$, Lei de Introdução às normas do Direito Brasileiro.
} 
formal), seja externamente (coisa julgada material). ${ }^{10} \mathrm{O}$ fenômeno, de fato, pode ser assim considerado à luz do processo de conhecimento. No entanto, pode haver formas de tutela jurisdicional que se realizam a despeito de não se formar a coisa julgada (p.ex., art. 304, § 6. ${ }^{\circ}$ do CPC).

Por fim, uma das mais relevantes notas da jurisdição: a imparcialidade e independência. É direito de todos ser ouvido e julgado por juiz ou tribunal competente, independente e imparcial, que não tenha sido previa e especificamente determinado para o caso (art. $\left.5^{\circ}, \mathrm{XXVII}, \mathrm{CF}\right)$.

A independência possui dupla vertente: a liberdade do Judiciário quanto a interferências institucionais do Legislativo e do Executivo (art. $2^{\circ}, \mathrm{CF}$ ) e o fato de o juiz, enquanto pessoa física, que personifica o órgão em nome de quem atua, estar submetido apenas ao direito e não a qualquer outro critério externo (Nery Jr., 2017, p. 173).

Em julgamento de caso levado à Corte Interamericana de Direitos Humanos, mencionou-se que "a intervenção de um juiz competente, independente e imparcial é um pressuposto de devido processo", sob pena de não existir "um verdadeiro processo, senão aparência de tal" (Fonseca, 2018, p. 48) ${ }^{11}$. De acordo com o precedente, a imparcialidade do tribunal corresponde à situação em que o juiz não possui interesse direto, ou uma posição predeterminada ao julgar determinado caso, ou ainda alguma forma de preferência por alguma das partes (Fonseca, 2017, p. 48).

A garantia do julgamento por um juiz imparcial, que já constava do art. 10 da Declaração Universal dos Direitos Humanos, também é assegurada no art. 14 do Pacto Internacional sobre Direitos Civis e Políticos ${ }^{12}$ e no art. $8^{\circ}$ do Pacto de São José da Costa Rica, ${ }^{13}$ como pontua José Miguel Garcia Medina (2020, p. 49).

A imparcialidade compõe o princípio do juiz natural. Esse princípio é considerado por Nelson Nery Junior como uma garantia tridimensional, que abarca as acepções de que não haverá tribunal de exceção e que todos possuem o direito de ser submetido a julgamento por um juiz competente, pré-constituído por lei e imparcial (Nery Jr., 2017, p. 166). Por Tribunal de exceção, compreende-se aquele que, independentemente da existência à época do fato, é designado para o julgamento de determinado causa por força de lei ou de outro ato que assim especifique.

Contudo, não é necessário se ater à ideia de tribunal de exceção para repudiar a noção de que o processo deve se desenvolver por meio de um juiz imparcial, principalmente por tudo que foi exposto até aqui e mormente por se tratar de aspecto derivado do devido processo legal (art. $5^{\circ}$, LIV, CF) (Medina, 2020, p. 49-50).

Em suma, é possível perceber que a atividade jurisdicional é aquela realiza e/ou declara o direito ao caso concreto e o faz por meio do processo, que deve observar garantias e direitos assegurados nos planos constitucional, infraconstitucional e internacional, por meio de tratados e convenções ratificados pelo Brasil.

Para que o conflito levado ao Judiciário seja extinto e a pacificação social alcançada em um processo de conhecimento - função precípua do processo -, reclama-se a prolação do ato perseguido desde o início da relação processual: a sentença. ${ }^{14}$ Entretanto, para que possa produzir efeitos, é preciso, antes, que a decisão exista e seja válida, sem o que restará inviabilizada a propositura da ação rescisória, objeto da próxima seção.

\footnotetext{
${ }^{10}$ Ada Pellegrini e outros, em vez da coisa julgada, citam a definitividade como característica da jurisdição (Grinover, A. P.; Dinamarco, C. R. \& Cintra, A. C. A. (2015). Teoria Geral do Processo. São Paulo: Malheiros., p. 168).

${ }^{11}$ Caso Uson Ramirez vs. Venezuela.

${ }^{12}$ Que dispõe: 1. Todas as pessoas são iguais perante os tribunais e as cortes de justiça. Toda pessoa terá o direito de ser ouvida publicamente e com devidas garantias por um tribunal competente, independente e imparcial, estabelecido por lei, na apuração de qualquer acusação de caráter penal formulada contra ela ou na determinação de seus direitos e obrigações de caráter civil. [...].

${ }^{13}$ Artigo $8^{\circ}$ - Garantias judiciais 1. Toda pessoa terá o direito de ser ouvida, com as devidas garantias e dentro de um prazo razoável, por um juiz ou Tribunal competente, independente e imparcial, estabelecido anteriormente por lei, na apuração de qualquer acusação penal formulada contra ela, ou na determinação de seus direitos e obrigações de caráter civil, trabalhista, fiscal ou de qualquer outra natureza.

${ }^{14}$ Sobre serem jurisdicionais os demais atos processuais que não a sentença, Athos Gusmão Carneiro cita o entendimento de Galeno Lacerda, segundo o qual somente atos que decidem questões durante o processo podem ser considerados jurisdicionais, do que aquele autor discorda, por conceber que qualquer atividade do juiz que ruma à sentença deve ser considerada jurisdicional, independente de seu caráter decisional, opinião também defendida por Frederico Marques (Carneiro, A. G. (2012). Jurisdição e competência. (18a. ed.) São Paulo: Saraiva, p. 28).
} 


\subsection{Ação rescisória e a hipótese veiculada no art. 966, I, do CPC/2015}

\subsubsection{Noções introdutórias}

A ação rescisória, ao lado da ação declaratória de inexistência ("querela nullitatis"), da reclamação e da ação anulatória, é considerada como meio autônomo de impugnação de decisões (Medina, 2017, p. 991). A diferença para os recursos é que esses são interpostos no bojo do próprio procedimento, ao passo que os meios autônomos de impugnação reclamam a formação de nova relação processual, distinta daquela em que proferida a decisão impugnada.

Disposta no art. 966 do CPC/2015, a rescisória exige que a decisão atacada seja, em regra, de mérito ${ }^{15}$ e transitada em julgado. Os vícios que autorizam a desconstituição da coisa julgada concentram, em sua maioria, defeitos vinculados ao plano da validade do ato jurídico ${ }^{16} \mathrm{e}$ são de tal ordem que o legislador lhes confere aptidão de relativizar uma garantia fundamental (art. $5^{\circ}$, XXXVI, da CF), um dos pilares do Estado Democrático de Direito, radicado na matriz de segurança jurídica.

Na perspectiva de um discurso pragmático, é fundamental, dentro do direito, que os problemas sejam resolvidos em algum momento e a coisa julgada, segundo Marinoni, Mitidiero e Sarlet (2018, p. 896) transforma a regra que traduz o discurso jurídico em um discurso prático.

A questão é que, padeça do vício que for (contanto, frise-se, que pertinente ao plano da validade do ato), se a decisão transitada em julgado não for questionada dentro do prazo de dois anos para propositura da ação rescisória (art. 975 do CPC), ela se tornará definitivamente estável. Teresa Arruda Alvim (2019, p. 389) leciona que após o transcurso do referido prazo:

[...] as decisões nulas não deixarão de sê-lo, mas, pelo menos, deixarão de ser vulneráveis, ainda que, ontologicamente, remanesçam nulas. Serão, no entanto, invulneráveis porque do único meio para desconstituí-las a parte não mais se poderá valer.

É a escolha que fez o legislador, ao se deparar com valores antagônicos e similarmente relevantes (justiça e segurança jurídica):

Ora prefere-se a justiça, admitindo que uma sentença proferida "contra legem", mesmo após o trânsito em julgado, possa ser modificada. Ora a segurança jurídica, inadmitindo que superado um certo prazo aquela sentença deixe de operar efeitos. (Gajardoni, 2000, p. 19)

A lei determina as decisões que, por razões graves, podem ser rescindidas, para garantia da segurança jurídica, dentro do prazo de dois anos. São elas: a decisão proferida por prevaricação, concussão ou corrupção do juiz (inc. I), proferida por juiz impedido ou juízo absolutamente incompetente (inc. II), for produto de dolo ou coação da parte vencedora em detrimento da parte vencida ou, ainda, de simulação ou colusão entre as partes, a fim de fraudar a lei (inc. III), ofender a coisa julgada (inc. IV), violar manifestamente norma jurídica (inc. V), for fundada em prova cuja falsidade tenha sido apurada em processo criminal ou venha a ser demonstrada na própria ação rescisória (inc. VI), se o autor obtiver, posteriormente ao trânsito em julgado, prova nova cuja existência ignorava ou de que não pôde fazer uso, capaz, por si só, de lhe assegurar pronunciamento favorável (inc. VII) e se for fundada em erro de fato verificável do exame dos autos (inc. VIII, 966, CPC).

Feito esse breve panorama geral, oferecem-se as condições mínimas e necessárias para descer com maior profundidade ao tema principal deste ensaio.

\footnotetext{
${ }^{15}$ Com exceção do disposto no $\$ 2^{\circ}$ do art. 966 , CPC.

${ }^{16}$ Excetuando-se a hipótese de obtenção de prova nova (cf. art. 966, VII, do Código de Processo Civil)
} 


\subsubsection{Das decisões proferidas por força de prevaricação, concussão e corrupção do juiz}

$\mathrm{O}$ artigo 966 do $\mathrm{CPC} / 2015$, que contempla as causas de rescindibilidade das decisões transitadas em julgado, estabelece logo em seu primeiro inciso a hipótese de cabimento que se coloca como tema do presente artigo.

Desde logo, observa-se que as mesmas causas que autorizam a rescindibilidade da decisão transitada em julgado configuram concomitantemente crimes previstos no Código Penal (arts. 319, 316 e 317). Os tipos penais estão previstos no Título XI, que trata "Dos Crimes contra a Administração Pública", dentro do Capítulo I, que cuida "Dos Crimes Praticados por Funcionário Público contra a Administração em Geral". Tratam-se de delitos cujo bem jurídico tutelado visa "preservar a regularidade da Administração Pública no que diz respeito ao 'exercício funcional' do sujeito ativo" (Mirabete, 2005, p. 741 751) O sujeito ativo deve ser funcionário público (no caso, o magistrado). O sujeito passivo pode ser União, Estados, o Distrito Federal, Municípios e as pessoas jurídicas mencionadas no art. $327, \S 1^{\circ}, \mathrm{CP}$, e, na concussão, secundariamente, quem sofreu a ação material (Carvalho, Carvalho \& Prado, 2015, p. 1345).

Por prevaricação entende-se o retardamento ou omissão da prática de ato que deveria ser realizado pelo funcionário público, decorrente das funções que lhe foi atribuída, conforme diç̧ão do art. 319 do Código Penal. ${ }^{17}$ Dentro da classificação clássica, é considerado delito de mão própria, pois deve ser praticado por funcionário público. Exige-se, também, o fim especial de agir, denominado de elemento subjetivo especial do tipo, que, no caso da prevaricação, consubstancia-se no “interesse ou sentimento pessoal". Segundo Cezar Roberto Bitencourt (2015, p. 105), o interesse pessoal pode ser material ou moral e satisfaz pretensão, ambição ou anseio do agente, enquanto o sentimento pessoal é um estado afetivo do próprio agente, que pode se manifestar como amor, ódio, carinho e vingança. Ausentes tais requisitos, a conduta é considerada atípica.

A concussão, por sua vez, segundo Pontes de Miranda, "[...] é exigência criminosa, direta ou indireta, para si ou para outrem, fundada em poder que tem, para vantagem ilegal ou imoral." (como citado por Buzaid, 1978, p. 13). Encontra adequação típica no art. 316 do Código Penal, que assim dispõe: "Exigir, para si ou para outrem, direta ou indiretamente, ainda que fora da função ou antes de assumi-la, mas em razão dela, vantagem indevida." ${ }^{18} \mathrm{O}$ núcleo do tipo consiste em "exigir", compreendido como ordem ou imposição, sendo a exigência relacionada com a função do agente, mesmo que antes de exercêla, ou ainda que licenciado o agente (Hungria, 1997).

A vantagem indevida, que constitui o elemento normativo do tipo, consiste na obtenção de benefício contrário ao direito, que pode ser material ou imaterial, pois quando o legislador quer restringir a vantagem à natureza econômica, o faz expressamente, conforme no caso do crime de extorsão (art. 158 do $\mathrm{CP}^{19}$ ) (Carvalho, Carvalho \& Prado, 2015, p. 1339). Cuida-se de infração penal unilateral, pois não se exige a participação de terceiro para a tipificação da conduta. O simples “exigir” já é suficiente para exaurir o tipo, de modo que a efetiva percepção da vantagem indevida é desnecessária para consumação do tipo penal.

Já a corrupção passiva, considerada, por Greco Filho (2019, p. 774), como irmã da concussão, consiste em "Solicitar ou receber, para si ou para outrem, direta ou indiretamente, ainda que fora da função ou antes de assumi-la, mas em razão dela, vantagem indevida, ou aceitar promessa de tal vantagem." (art. 317 do CP). Difere da concussão pelo fato de o verbo "solicitar", que constitui um dos núcleos do tipo penal da corrupção passiva, encerrar menor carga impositiva em relação ao "exigir" do art. 316 do CP, porquanto a mera solicitação de vantagem já é suficiente para configurar a conduta, independentemente de qualquer outra postura do sujeito ativo.

\footnotetext{
${ }^{17}$ Art. 319. Retardar ou deixar de praticar, indevidamente, ato de ofício, ou praticá-lo contra disposição expressa de lei, para satisfazer interesse ou sentimento pessoal: Pena - detenção, de três meses a um ano, e multa.

${ }^{18}$ Tal dispositivo foi recentemente modificado pela Lei no 13.964, de 2019 (Pacote Anticrime), que alterou a pena máxima de 8 (oito) para 12 (doze) anos, passando a redação a constar do preceito secundário: "Pena - reclusão, de 2 (dois) a 12 (doze) anos, e multa."

${ }^{19}$ Art. 158 - Constranger alguém, mediante violência ou grave ameaça, e com o intuito de obter para si ou para outrem indevida vantagem econômica, a fazer, tolerar que se faça ou deixar de fazer alguma coisa: Pena - reclusão, de 4 (quatro) a 10 (dez) anos, e multa.
} 
O delito de corrupção passiva pode ser unilateral ou bilateral (exige a presença de terceiro para a tipificação da conduta): unilateral, quando o agente público solicita a vantagem indevida de particular e este não aceita, e bilateral, quando este aceita a vantagem indevida ou promessa desta, ou quando efetivamente a recebe (Mirabete, 2005, p. 741-751). Nesse caso, o particular incorre na conduta tipificada no art. 333 (corrupção ativa) e o funcionário público no tipo penal do art. 317, ambos do Código Penal, caracterizando exceção à teoria monista adotada em seu art. 29. ${ }^{20}$ Segundo Luiz Regis Prado, Gisele Mendes de Carvalho e Erika Mendes de Carvalho, o crime de corrupção fere o próprio Estado Democrático de Direito, uma vez que atinge o bom e regular funcionamento da Administração Pública, "que deve atuar sempre com objetividade e imparcialidade a serviço dos interesses gerais, segundo exigência da própria Constituição Federal [...].” (2015, p. 1347).

Para Nelson Nery Junior, não se exige prévia condenação pela prática dos referidos delitos, uma vez que a prova pode ser perfeitamente realizada no bojo da ação rescisória. Todavia, se o juiz for condenado na seara criminal, a decisão inexoravelmente repercutirá na esfera cível e poderá ser aproveitada para fins de autorizar a propositura de rescisória pautada no inciso I do artigo 966 do CPC/2015. Já se o magistrado for absolvido na seara criminal, isso, por si só, não impede o manejo do instrumento processual em destaque, na medida em que, na linha dos ensinamentos de Nelson Nery Junior, a prova da prevaricação, concussão ou corrupção poderá ser realizada durante a instrução da ação rescisória, em ordem a ensejar a procedência dos pedidos se caracterizada alguma daquelas três situações (Nery Jr., 2018, p. 2142).

\subsection{Sentença proferida nas hipóteses do 966, inciso I, do CPC/2015: causa de rescindibilidade ou de inexistência da relação jurídico-processual?}

\subsubsection{Delineamento da controvérsia}

O legislador possibilita a propositura de ação rescisória no prazo de dois anos quando da prolação de sentença em que o julgador tenha decidido em decorrência de corrupção, concussão ou prevaricação. Se rescindíveis, é porque envolvem defeitos no plano da validade do ato jurídico, os quais, se não invocados dentro do lapso decadencial, precluem no tempo, gerando a coisa "soberanamente julgada".

Uma releitura da questão, porém, sugere que a discussão deve deslocar-se para outro plano da chamada escada ponteana: o do ser ou não ser do ato jurídico (Alvim, 2019, p. 180).

Como exposto, dentre os pressupostos de existência do processo, encontram-se a jurisdição, correspondente à investidura do magistrado para decidir o conflito levado ao Judiciário, a citação, entendida como cientificação do réu acerca do processo - cuja ausência ou defeito pode configurar a hipótese mais conhecida da "querela nullitatis" (Marinoni, Mitidiero, 2017, p. 1037) -, e a petição inicial, que é o meio pelo qual o autor deduz sua pretensão.

A jurisdição corresponde à função e ao poder do magistrado de, no exercício da soberania estatal, decidir a celeuma, por meio da aplicação da norma ao caso concreto, com imparcialidade e com caráter imperativo. O Poder Judiciário, sob certo ponto de vista, está "acima" das partes e para além dos interesses delas. Isso não significa dizer que as partes ficam à mercê de arbitrariedades e que, por estar acima delas, o juiz poderia, ao pretexto de imparcialidade, julgar a causa como bem lhe aprouver. Ao revés, é inegável a relevância do papel das partes dentro do processo, ao deduzir os pedidos de forma clara, ao exercer o contraditório e a ampla defesa, ao auxiliar o juiz com, dentre outros fatores, com a produção de um arcabouço probatório capaz de ensejar a decisão mais adequada ao caso concreto (art. $6^{\circ}$ do $\mathrm{CPC}$ ), dentre outras hipóteses.

Quando um juiz é subornado por uma das partes para prejudicar a outra, favorecer a si próprio, ou as duas modalidades conjuntamente, independentemente do caráter econômico do favor, ou ainda quando age para satisfação de interesses ou de sentimentos próprios, coloca-se em dúvida se houve efetivo exercício da jurisdição.

${ }^{20}$ Art. 29 - Quem, de qualquer modo, concorre para o crime incide nas penas a este cominadas, na medida de sua culpabilidade. 
Nessas hipóteses, o magistrado não se vale das provas produzidas ao longo da instrução processual e dos argumentos das partes para definitivamente aplicar o direito ao caso concreto, decidindo conforme os preceitos que fundamentam o ordenamento jurídico. Não se está diante propriamente do julgamento de uma causa, enquanto exercício do poder soberano advindo da jurisdição, mas sim de um arremedo de sentença, que tem como causa a prática de crime.

A decisão, portanto, em vez de dirimir o conflito, constitui instrumento para prática dolosa de delitos de prevaricação, concussão ou corrupção. ${ }^{21}$ Ela deixa de ser resultado de uma exteriorização da vontade estatal de resolução de conflito e passa a converter-se em um meio para a prática delitiva, afastando-se das finalidades mais elementares do direito.

José Miguel Garcia Medina (2020, p. 281) nomina a vontade de exercer a jurisdição como "animus judicandi", termo comumente utilizado na seara processual penal para mencionar a "divergência intencional entre a vontade real do juiz e a vontade por ele declarada." O autor (2020, p. 1454) sustenta a inexistência jurídica de sentença, quando ausente aquele “animus", concluindo que nessa hipótese:

[...] o juiz intencionalmente declarará algo (a decisão proferida) que não corresponde aquilo que quer fazer (no caso, o ato criminoso). [...] Trata-se de um arremedo de sentença, já que [...] se estará diante da prática de ato criminoso dissimulado de sentença.

Nesses casos, será importante delimitar o momento a partir do qual o "animus judicandi” desapareceu, pois só assim será possível divisar os atos inexistentes - ou não atos - dos que preencheram o suporte fático previsto na norma e, por conseguinte, poderão ser aproveitados.

A jurisdição não é exercida quando se leva em consideração que o julgador, ao decidir pautado na atuação criminosa, agiu em favor de alguma das partes, ou seja, violando assim a imparcialidade exigida no exercício de sua função como a independência.

Por independente, compreende-se o juiz que decide de acordo com a livre convicção, contanto que pautado no direito, na lei e no substrato probatório produzido nos autos, e não a critérios particulares ou discriminatórios (Nery Jr., 2017, p. 173).

A possibilidade de julgar de acordo com o seu convencimento, desde que motivado e fundamentado (art. 93, IX, CF e arts. 371 e 489, II, ambos do CPC), é a denominada independência funcional do magistrado.

Ao incorrer em alguma das hipóteses previstas no art. 966, inc. I, do CPC/2015, o magistrado sofre influências externas e, por conta disso, decide a causa não com base no material probatório e argumento das partes, mas para auferir benefícios prometidos ou pagos por terceiros, satisfazer interesse ou sentimento pessoal.

Sobre a imparcialidade, embora não prevista expressamente no rol de garantias processuais estatuídas na Constituição Federal, decorre implicitamente do princípio do juiz natural (art. $5^{\circ}$, LIII), do devido processo legal (art. $5^{\circ}$, LIV) e de acordos e tratados internacionais dos quais o Brasil é signatário, independentemente da natureza jurídica que se lhes possa atribuir. ${ }^{22}$

Embora tratando dentro da seara penal, Guilherme Madeira Dezem cita alguns exemplos de atos inexistentes: aqueles proferidos por quem não é juiz, quando da ocorrência de incompetência inconstitucional e em caso de sentença sem dispositivo (2020, p. 1177). Dentro do primeiro exemplo, cujo viés acadêmico se sobrepõe ao pragmático, menciona o caso de juiz que tenha julgado por corrupção, pois, sendo a imparcialidade uma das características da jurisdição, "nas hipóteses em que o juiz foi corrompido por uma das partes não se terá essa característica da jurisdição, e, então, teremos caso de inexistência” (Dezem,

\footnotetext{
${ }^{21}$ Não se admite a modalidade culposa para tais delitos.

${ }^{22} \mathrm{Se}$ alçados à categoria de norma constitucional ou não. Discussão apresentada por José Miguel Garcia Medina em seu Código de Processo Civil comentado, ao tratar acerca do art. $7^{\circ}, \mathrm{CPC}$, p. 49.
} 
2020, p. 1177). Em apoio ao entendimento endossado, o autor apresenta relevante julgado sobre o tema, ao justificar sua opinião contrária àqueles que entendem que a inexistência produzirá efeitos em caso de absolvição ${ }^{23}$ :

[...] condutas contrárias à verdade, fraudulentas ou procrastinatórias conspurcam o objetivo publicístico e social do processo, a merecer uma resposta inibitória exemplar do Judiciário. 11. Portanto, visto sob esse prisma, não há como se tolerar, como argumento de defesa, suposta inobservância à segurança jurídica quando a estabilidade da decisão que se pretende seja obedecida é assentada justamente em situação de fato e em comportamento processual que o ordenamento jurídico visa coibir. (Superior Tribunal de Justiça, 2014) ${ }^{24}$

Semelhante lógica orienta a aplicação do argumento na seara civil, pois a segurança jurídica, visada pelo legislador ao fixar um limite temporal para a propositura da ação rescisória, não pode ser pautada em decisão fundada em situação fraudulenta e contrária à verdade, sob pena de se aceitar como exercício da jurisdição aquilo que verdadeiramente não o é.

\subsubsection{Imparcialidade e nulidade}

Parece não remanescer dúvidas de que o juiz subornado, ou que tenha praticado algum dos delitos previstos no art. 966, I, do CPC/2015, age de modo parcial e, como tal, deve ser repelido.

Interessa, porém, relacionar aquele dispositivo com a hipótese elencada pelo inciso II daquele mesmo preceito normativo, que trata da decisão proferida por juiz impedido.

Percebe-se, antes de mais nada, que o legislador selecionou o impedimento como hipótese de cabimento da ação rescisória, deixando de fora - ao que parece, de maneira propositada - a suspeição. A exclusão, a princípio, não parece a mais adequada, pois ambos os institutos têm origem comum: a imparcialidade. ${ }^{25}$

Não há como negar que o juiz impedido age com parcialidade, violando o direito da parte ter um julgamento livre e justo. ${ }^{26} \mathrm{~A}$ diferença é que nos casos de impedimento o juiz efetivamente julga a causa, ou, em termos menos redundantes, exerce a jurisdição no caso concreto, o que não ocorre nas hipóteses previstas no inciso I do artigo 966 do CPC/2015. Nesse último caso, o magistrado simplesmente usa do julgamento como meio para prática de um crime, ou seja, não há decisão que não propriamente a exteriorização da prática delituosa.

Por isso, compreende-se que o impedimento configura grave nulidade apta a ensejar a desconstituição da coisa julgada, mas não se trata de vício transrescisório como a causa anteriormente abordada. Assim, se detectada alguma das

\footnotetext{
${ }^{23}$ Retoma-se, aqui, o conceito de Revisão Criminal, que se constitui em modalidade de impugnação de sentença transitada em julgado que contenha erro judiciário. Não se admite, regra geral, o manejo de tal meio de impugnação para revisão de sentença absolutória, bem como não se admite a chamada revisão pro societate, eis que "o acusado absolvido com sentença transitada em julgado não pode ser novamente julgado pelos mesmos fatos.” Dezem, G. M. (2020). Curso de Processo Penal. (6a. ed. rev., atual. e ampl.) São Paulo: Revista dos Tribunais, p. 1179 e 1373-1374.

${ }^{24}$ REsp. no 1.324.760 - SP (2011/0153653-7) Relator: Ministro Sebastião Reis Júnior. R.P/Acórdão: Ministro Rogerio Schietti Cruz DJe: 18/02/2015 Julgado em 16 de dezembro de 2014.

${ }^{25}$ José Miguel Garcia Medina leciona, sobre o assunto, que a suspeição também deveria estar inserida nas hipóteses de rescindibilidade da decisão. Cf. Código de Processo Civil comentado, p. 281

${ }^{26}$ As causas de impedimento estão expressamente elencadas no art. 144 do CPC: "Há impedimento do juiz, sendo-lhe vedado exercer suas funções no processo:

I - em que interveio como mandatário da parte, oficiou como perito, funcionou como membro do Ministério Público ou prestou depoimento como testemunha; II - de que conheceu em outro grau de jurisdição, tendo proferido decisão;

III - quando nele estiver postulando, como defensor público, advogado ou membro do Ministério Público, seu cônjuge ou companheiro, ou qualquer parente, consanguíneo ou afim, em linha reta ou colateral, até o terceiro grau, inclusive;

IV - quando for parte no processo ele próprio, seu cônjuge ou companheiro, ou parente, consanguíneo ou afim, em linha reta ou colateral, até o terceiro grau, inclusive;

V - quando for sócio ou membro de direção ou de administração de pessoa jurídica parte no processo;

VI - quando for herdeiro presuntivo, donatário ou empregador de qualquer das partes;

VII - em que figure como parte instituição de ensino com a qual tenha relação de emprego ou decorrente de contrato de prestação de serviços;

VIII - em que figure como parte cliente do escritório de advocacia de seu cônjuge, companheiro ou parente, consanguíneo ou afim, em linha reta ou colateral, até o terceiro grau, inclusive, mesmo que patrocinado por advogado de outro escritório;

IX - quando promover ação contra a parte ou seu advogado.
} 
hipóteses de impedimento após o trânsito em julgado da decisão, caberá à parte alegá-lo dentro do prazo de dois anos (art. 975 do $\mathrm{CPC} / 2015)$.

O termo inicial do prazo para propositura da ação rescisória, em regra, será de dois anos a partir do trânsito em julgado da última decisão proferida no processo, salvo a hipótese do inciso VI do artigo 966 do CPC/2015, que trata da prova nova. Nesse caso, o termo inicial do prazo será a data de descoberta da prova nova (art. 975, §2² do CPC/2015).

Em estudo inovador, Márcio Carvalho Faria (2013, p. 241) defende a criação de prazos diferentes para ajuizamento da demanda rescisória, de acordo com as peculiaridades de cada hipótese. Conforme o autor, após o conhecimento da causa do vício, o prejudicado teria o prazo de trinta a noventa dias para ajuizar a demanda. E para evitar a possibilidade de ações serem ajuizadas indefinidamente, segundo proposta "de lege ferenda", instituir-se-ia o prazo máximo de oito anos, que, segundo o autor, seria interregno razoável para ainda se debater eventual vício, após o qual a segurança jurídica seria efetivada por meio da coisa soberanamente julgada.

O raciocínio é de grande valia para os casos de decisões proferidas por juiz impedido, pois soa mais adequado, do ponto de vista lógico e jurídico, que o prazo para propositura da ação rescisória iniciasse somente a partir do conhecimento do fato gerador do impedimento (ou da suspeição, para quem acredita que esse vício também autoriza a propositura de ação rescisória) (Medina, 2020, p. 281), se este se deu após o trânsito em julgado da decisão. Se a parte sequer conhecia o fator impeditivo que acometia o julgador, não poderia alegá-lo dentro do biênio legal. Nesse caso, o direito poderia socorrer aos que não dormem, em trocadilho com o brocardo latim "Dormientibus Non Sucurrit Ius".

A mesma ideia se aplica à sentença proferida em decorrência de prevaricação, concussão ou corrupção do juiz, com a distinção de que, nesse particular, não incidiria o óbice temporal, por se tratar, como exposto, de sentença inexistente, impugnável por meio de ação declaratória imprescritível.

No anteprojeto que deu origem ao CPC de 2015 havia expressa menção ao prazo para ajuizamento da ação rescisória nas hipóteses encartadas no atual art. 966, I, que seria a partir do trânsito em julgado da sentença condenatória no crime (art. 873 do anteprojeto). ${ }^{27}$ A previsão foi mantida na versão do projeto do Senado (artigo 928 do projeto de novo CPC), mas a Câmara dos Deputados extinguiu diferenciação de prazos (Medina, 2014, online).

Se permanecesse a redação original do projeto, a situação, de certo modo, estaria resolvida e poderia reduzir substancialmente o número de decisões que, apesar de eivadas de parcialidade, tornaram-se definitivas. Porém, admitir essa hipótese implicaria aceitar que o ato, mesmo nulo, efetivamente existiu - tanto que suscetível de impugnação dentro de determinado prazo decadencial -, fazendo com que algo juridicamente inexistente passe a existir pelo simples decurso do tempo, o que iria de encontro com a orientação encampada neste breve ensaio.

\section{Conclusão}

A sentença proferida em casos em que o julgador tenha comprovadamente agido por força de prevaricação, concussão ou corrupção não pode ser considerada como causa de nulidade, com a consequente limitação temporal de dois anos prevista para ação rescisória, mas sim como hipótese de inexistência do ato jurídico, que sobrevive ao mero decurso do tempo.

A jurisdição, que constitui um dos pressupostos de existência da relação jurídico-processual, tem como uma de suas principais características a imparcialidade e a independência, que são profundamente vulneradas nas hipóteses de prevaricação, concussão ou corrupção do juiz. Se não há imparcialidade, não há jurisdição, consequentemente não há (no sentido de existir) processo. Falta-lhe a necessária vontade de exercer a jurisdição ("animus judicandi”).

Admitir como nulas e rescindíveis decisões proferidas nessas circunstâncias é assumir que passem a existir e ter

${ }^{27}$ Embora, como já mencionado, alguns autores entendem que a prova possa ser feita dentro da própria ação rescisória, como Nelson Nery Jr. Código de Processo Civil comentado, p. 2142. 
validade pelo simples decurso do tempo, o que não se revela concebível para algo que não passa de um arremedo de sentença, ou, por outras palavras, de um ato criminoso dissimulado de sentença (Medina, 2020, p. 1454).

Pensar de forma diversa implicaria que a segurança jurídica, que permeou o legislador ao delimitar um prazo fixo para propositura da rescisória, caísse por terra, por se estar diante de decisão lastreada em conduta que o ordenamento jurídico abomina e, dentro da seara penal, proíbe de maneira peremptória.

\section{Referências}

Alvim, T. A. (2019). Nulidades do Processo e da Sentença. (10a ed). Thomson Reuters Brasil.

Bittencourt, C. R. (2015). Tratado de Direito Penal. Parte Especial. (2a ed). Saraiva.

Buzaid, A. (1978) Da Responsabilidade do Juiz. Revista de Processo.

Caldas, F. D. A. (2016). Curso de Processo Civil: parte geral. Malheiros

Calmon de Passos, J. J. (1998). Comentários ao Código de Processo Civil. (8a. ed) Forense.

Carneiro, A. G. (2012). Jurisdição e competência. (18a. ed.) Saraiva

Carvalho, M. F. (2013). A Ação Rescisória no Projeto de Novo Código de Processo Civil e uma sugestão de lege ferenda. Revista de Processo.

Cunha, M. F. \& Freire, R. C. (2017) Novo Código de Processo Civil. (7a. ed.) Juspodivm.

De Lucca, R. R. (2011). Querela nullitatis e réu revel não citado no processo civil brasileiro. Revista de Processo. Ed. RT.

Dezem, G. M. (2020). Curso de Processo Penal. (6a ed.), Revista dos Tribunais

Didier Jr, F. (2017). Curso de Direito Processual Civil. (19a ed.), Juspodvim.

Donizetti, E. (2017). Novo Código de Processo Civil anotado. (2a. ed.) Atlas.

Fônseca, V. (2018). Processo Civil e Direitos Humanos. Thomson Reuters Brasil.

Gajardoni, F. D. F (2000). Sentenças inexistentes e a querela nullitatis. Revista Jurídica da Universidade de Franca.

Godoy, A. S. (1995) Introdução à pesquisa qualitativa e suas possibilidades. RAE - Revista de Administração de Empresas. 35(2)

Gomes Junior, L. M.; Lima, D. A. \& Novak, M. S. (2020). Querela Nullitatis e Segurança Jurídica. Research, Society and Development. 9(10)

Greco, R. (2019). Curso de Direito Penal: parte especial. (16a ed.): Impetus.

Grinover, A. P.; Dinamarco, C. R. \& Cintra, A. C. A. (2015). Teoria Geral do Processo. Malheiros.

Hungria, N. (1997) Código Penal e sua interpretação jurisprudencial. (6a ed.) Revista dos Tribunais.

Marinoni, L. G.\& Mitidiero, D. (2017). Novo Código de Processo Civil Comentado. Revista dos Tribunais.

Marinoni, L. G.; Mitidiero, D. \& Sarlet, I. W. (2018). Curso de Direito Constitucional. (7a ed.) Saraiva Educação.

Marques, J. F. Instituições de Direito Processual Civil, (4a ed.).

Medina, J. M. G. (2014). Assessoramento de julgador não pode influenciar parcialidade. Conjur. https://www.conjur.com.br/2014-mar-10/processoassessoramento-julgador-nao-influenciar-parcialidade\#_ftn8_8831.

Medina, J. M. G. (2020). Código de Processo Civil comentado. (6a. ed.) Revista dos Tribunais.

Medina, J. M. G. (2020). Curso de Direito Processual Civil Moderno. (3a ed.). Revista dos Tribunais.

Mirabete, J. F. (2005) Dos sujeitos ativos nos Delitos de corrupção. Revista dos Tribunais. (834).

Nery Jr, N. (2017). Princípios do Processo na Constituição Federal. (13a. ed.). Revista dos Tribunais.

Pereira, A. S., et al. (2018). Metodologia da pesquisa científica. UFSM. https://repositorio.ufsm.br/bitstream/handle/1/15824/Lic_Computacao_MetodologiaPesquisa-Cientifica.pdf?sequence=1.

Pontes De Miranda, F. C. (1974). Tratado de direito privado. (4a ed). RT

Prado, L. R.; Carvalho, E. M.\& Carvalho, G. M. (2015) Curso de Direito Penal Brasileiro. (14a ed.) Revista dos Tribunais.

Tesheiner, J. M. (2001). Eficácia da sentença e coisa julgada no processo civil. Ed. RT. 
Research, Society and Development, v. 10, n. 2, e53710212779, 2021

(CC BY 4.0) | ISSN 2525-3409 | DOI: http://dx.doi.org/10.33448/rsd-v10i2.12779

Theodoro Junior, H. (1980) Nulidade, Inexistência e Rescindibilidade da Sentença. Revista de Processo. 19.

Watanabe, K. (1980). Controle jurisdicional e mandado de segurança contra atos judiciais. Revista dos Tribunais. 